パーキンソン病患者の視覚誘発電位一痴呆の有無による検討

\begin{tabular}{|c|c|c|c|c|}
\hline 奥田 & 文悟 & 立花 & 久大 & 武田 \\
\hline 川端 & 啓太 & 戸田 & 和夫 & 杉田 \\
\hline
\end{tabular}

\begin{abstract}
〈要 約> パーキンンン $(\mathrm{P})$ 病における視覚誘発電位 (VEP) について, 痴呆との関連を検討した。 $\mathrm{P}$ 病患者27例の pattern reversal VEP を，痴呆を有する（D）群10名と痴呆を有しない（nD）群17名に つき対照群14名と比較した。平均 $\mathrm{P} 100$ 潜時は $\mathrm{D}$ 群に执いてのみ, $\mathrm{nD}$ 群や対照群に比して有意に延長し ていた。 平均 $\mathrm{P} 100$ 振幅は, 3 群間で有意な差を認めなかった。 D 群の P100潜時は年齢・重症度と明らか な関連は認められなかった。 以上の結果より，P病の D 群における 100 潜時の延長は, 網膜レベルより も中枢の視覚伝導路における機能的障害を示唆するものと考兄られた。
\end{abstract}

Key words : Parkinson 病, 視覚誘発電位, 疾呆

\section{緒言}

パーキンソン $(\mathrm{P})$ 病においては通常視覚異常を伴わ ないとされているが, 電気生理学的検査の普及に伴い, 視覚誘発電位 (VEP) の異常を認める報告が散見され る112). しかし, VEP の異常所見も様々であり, そのメ カニズムについても一定の見解が得られていな (3)4). P 病は neurotransmitter の異常によって生じる 疾患の代表的なものであり, neurotransmitter の誘発 電位に及ぼす影響についても未解決の点が多い. 近年, $\mathrm{P}$ 病に沶いて比較的高率に疾呆を伴うことが指摘され て扣り ${ }^{5)}$, 痴呆を有する例で誘発電位や事象関連電位 の異常を認める報告もある67). 我々はこの点に着目 し，P病の VEP 所見を痴呆の有無につき検討した。

\section{対象および方法}

$\mathrm{P}$ 病患者 27 名, 与ち痴呆を有する D 群 10 名(男 5 例・ 女 5 例), 痴呆を有しない $\mathrm{nD}$ 群 17 例 (男 8 例・女 9 例) と，年齢を対応させた神経疾患を有しない対照 (C) 群 14名（男 6 例・女 8 例）を対象とした。いずれの例も 矯正視力 0.7 以上で視野異常なく, 眼科疾患を有しない ものとした。疾呆の診断基準は DSM-III-R を用い ${ }^{8)}$, 評 価尺度として Mini-Mental State Examination (MMSE) を施行した ${ }^{9)}$. $\mathrm{P}$ 病の平均罹病期間は $\mathrm{nD}$ 群 で47.5力月, D 群で71.3力月であった. $\mathrm{P}$ 病患者は全例 投薬を継続したままで検査を施行したが， $\mathrm{nD}$ 群の 4

B. Okuda, H. Tachibana, M. Takeda, K. Kawabata, K. Toda, M. Sugita：兵庫医科大学第五内科 受付日：1992。1．10，採用日：1992.3．4
例を除いてすべて L-dopaを服用していた．Trihexyphenidyl $\mathrm{HCl}$ は $\mathrm{nD}$ 群の 6 例, $\mathrm{D}$ 群の 4 例に投与され ていた.VEPの刺激は $1 \mathrm{~Hz} の$ pattern reversal checkerboardを用い，格子角と視角はそれぞれ1.1 度，17度とした．記録関電極を外後頭結節より $5 \mathrm{~cm}$ 上 方の正中後頭部 $\mathrm{Oz}$ と, $\mathrm{Oz}$ より左右に $5 \mathrm{~cm}$ 離れた $\mathrm{O}_{1}$, $\mathrm{O}_{2}$ に置き，不関電極を正中前頭部に置いて誘発電位を 記録した。フィルターは1 $100 \mathrm{~Hz}$ ，分析時間は200 msec として100回加算した。. 左右の単眼全視野刺激に より $\mathrm{O} z$ に誘発された $\mathrm{P} 100$ 電位の潜時, 振幅を平均し 比較検討した。 P100振幅は N75と P100の頂点間振幅 とし，N75が欠如している場合は基線と P100頂点間拡 幅とした。統計学的な有意差の検定は modified $t$ 検 定 ${ }^{10)}$ 施行し, 回帰分析には Pearson's rを用いた。

\section{成 績}

表 1 に示寸如く, $\mathrm{C}$ 群・ $\mathrm{nD}$ 群・ $\mathrm{D}$ 群間の年齢に有意 な差異は認められなかった。 $\mathrm{C}$ 群・ $\mathrm{nD}$ 群・D 群の平均 $\mathrm{P} 100$ 潜時の比較では, $\mathrm{D}$ 群において $\mathrm{C}$ 群や $\mathrm{nD}$ 群に比

表 1 パーキンソン病と対照群における平均 $\mathrm{P} 100$ 潜時と振幅

\begin{tabular}{c|c|c|c}
\hline $\begin{array}{c}\text { Subjects } \\
(\mathrm{n})\end{array}$ & $\begin{array}{c}\text { Age } \\
(\text { years })\end{array}$ & $\begin{array}{c}\text { Latency } \\
(\mathrm{ms})\end{array}$ & $\begin{array}{c}\text { Amplitude } \\
(\mu \mathrm{V})\end{array}$ \\
\hline D-PD (10) & $72.6 \pm 3.9$ & $120.0 \pm 15.2^{*}$ & $6.1 \pm 3.5$ \\
nD-PD (17) & $67.4 \pm 6.9$ & $106.3 \pm 11.1$ & $8.1 \pm 4.3$ \\
control (14) & $70.4 \pm 5.8$ & $105.1 \pm 10.0$ & $9.9 \pm 3.9$ \\
\hline
\end{tabular}

${ }^{*} \mathrm{p}<0.05$ as compared to $\mathrm{nD}-\mathrm{PD}$ or control

$\mathrm{D}-\mathrm{PD}$; 痴呆を有するパーキンンン病群 $\mathrm{nD}-\mathrm{PD}$; 痴呆を有さないパーキンソン病群 
Right Eye

0 ,

$\mathrm{Oz}$

$\mathrm{O}_{2}$

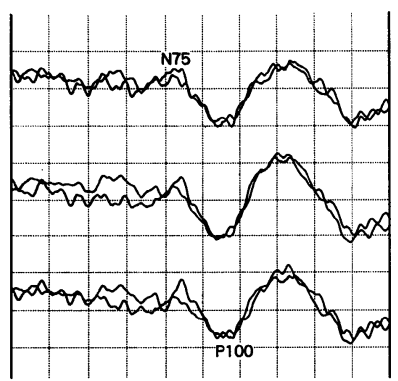

O,

Oz

$\mathrm{O}_{2}$

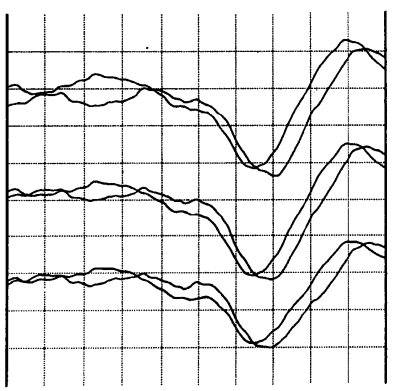

77y.o. F (Control)

O,

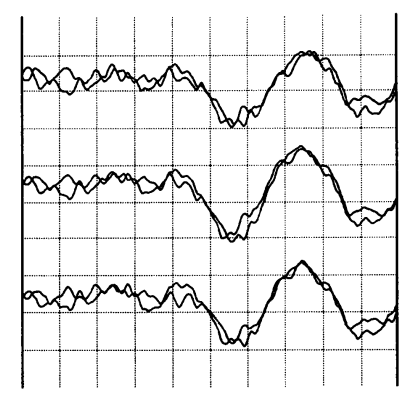

75y.o. F (D-PD)

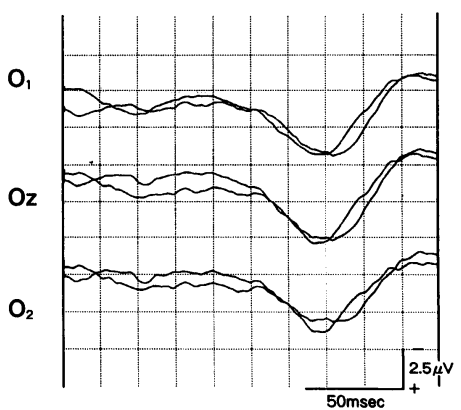

図 1 対照例（上段）とD-PD 例（下段）の pattern reversal VEP. 対照例と D-PD 例の平均 P100潜時は，それぞれ108.5msec，133msec と，D-PD 例で延長している.

表 2 パーキンソン病の各重症度に扮ける $\mathrm{P} 100$ 潜時と振幅

\begin{tabular}{|c|c|c|c|c|}
\hline \multirow{2}{*}{$\begin{array}{l}\text { Yahr's } \\
\text { stage }\end{array}$} & \multicolumn{2}{|c|}{$\mathrm{nD}-\mathrm{PD}$} & \multicolumn{2}{|c|}{ D-PD } \\
\hline & $\begin{array}{l}\text { latency } \\
\text { (ms) }\end{array}$ & $\underset{(\mu \mathrm{V})}{\text { amplitude }}$ & $\begin{array}{l}\text { latency } \\
\text { (ms) }\end{array}$ & $\underset{(\mu \mathrm{V})}{\text { amplitude }}$ \\
\hline \multirow{2}{*}{ I } & 97.3 & 6.6 & $(-)$ & $(-)$ \\
\hline & \multicolumn{2}{|c|}{$\mathrm{n}=1$} & \multicolumn{2}{|c|}{$\mathrm{n}=0$} \\
\hline \multirow{2}{*}{ II } & $103.0 \pm 9.5$ & $8.6 \pm 4.5$ & 122.0 & 10.0 \\
\hline & \multicolumn{2}{|c|}{$\mathrm{n}=5$} & \multicolumn{2}{|c|}{$\mathrm{n}=1$} \\
\hline \multirow{2}{*}{ III } & $108.5 \pm 12.6$ & $8.2 \pm 4.7$ & $120.0 \pm 18.3$ & $7.6 \pm 5.6$ \\
\hline & \multicolumn{2}{|c|}{$\mathrm{n}=10$} & \multicolumn{2}{|c|}{$\mathrm{n}=3$} \\
\hline \multirow{2}{*}{ IV } & 108.5 & 5.3 & $121.1 \pm 18.4$ & $4.8 \pm 2.0$ \\
\hline & \multicolumn{2}{|c|}{$\mathrm{n}=1$} & \multicolumn{2}{|c|}{$\mathrm{n}=5$} \\
\hline \multirow{2}{*}{ v } & $(-)$ & $(-)$ & 112.5 & 4.7 \\
\hline & \multicolumn{2}{|c|}{$\mathrm{n}=0$} & \multicolumn{2}{|c|}{$\mathrm{n}=1$} \\
\hline
\end{tabular}

して有意な潜時の延長を認めた $(\mathrm{p}<0.05$, 図 1$)$. 左 眼刺激と右眼刺激間の差である interocular difference $カ 38 \mathrm{msec}$ 以上の例は, C 群 2 例, $\mathrm{nD}$ 群 2 例, $\mathrm{D}$ 群 3 例であった. $\mathrm{C}$ 群・ $\mathrm{nD}$ 群・D 群の $\mathrm{P} 100$ 平均振幅 の比較では, $\mathrm{P}$ 病特に $\mathrm{D}$ 群において振幅が低下する傾 向があったが有意な差ではなかった。P病における平 均 $\mathrm{P} 100$ 潜時, 振幅と重症度との関連を表 2 に示す。
$\mathrm{Yahr}$ 分類では $\mathrm{nD}$ 群でII・III度の例が多く，D群では III度以上の重症例が多い傾向があった。平均潜時は, $\mathrm{nD}$ 群に打いては I ・II 度の軽症例に比して III・IV度の 重症例で延長していたが，D群においては一定の傾向 は認めなかった。平均振幅は，D群に打いて重症化す るにつれて減少する傾向にあったが，nD群において は一定の傾向を認めなかった（表 2 ）.

DSM-III-R の診断基準により痴呆の有無を判定し たが, MMSE Scoreでは $\mathrm{nD}$ 群は26点以上(平均 28.6), $\mathrm{D}$ 群は19点より25点まで (平均22.8) の得点で あった. 平均 P100潜時と MMSE Score との関連を検 討すると, 得点が低下するにつれて潜時が延長する傾 向があるが有意水準には達しなかった $(0.05<p<$ 0.1 , 図 2 ). 平均 P100振幅と MMSE Score との間に は一定の傾向は認めなかった. 平均 P100潜時と年齢と の関連を C 群で検討すると，加龄と潜時の間に有意な 相関関係は認められなかった $(\mathrm{p}>0.1$, 図 3$)$. 健康人 に打いては加齢に伴ってP100潜時が延長すると報告 されているが11)，対象とした人数と年齢幅が少ないこ とより有意水準には達しなかったものと推定される。 $\mathrm{P}$ 病では, $\mathrm{nD}$ 群においてのみ平均 $\mathrm{P} 100$ 潜時と加龄と の間に有意な相関を認めた. $\mathrm{nD}$ 群は全例期待値 $\pm 2 \mathrm{SD}$ 


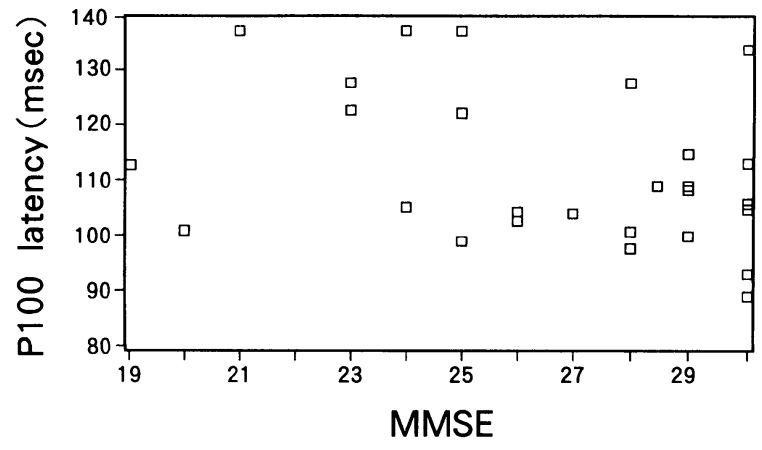

図 2 パーキンソン病のP100潜時と Mini-Mental State Examination Score (MMSE) との関係. MMSE が低下するにつれて P100潜時が延長する傾 向がある $(r=0.335,0.1>p>0.05)$.

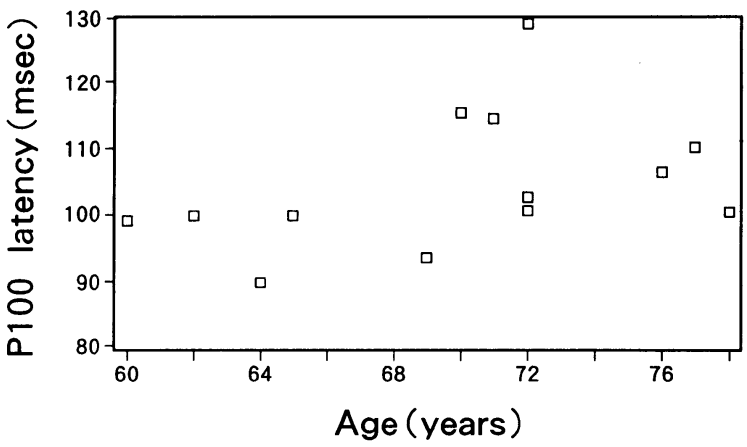

図 3 対照群における $\mathrm{P} 100$ 潜時と年齢との関係. 年齢 と P100潜時には有意な相関はない。

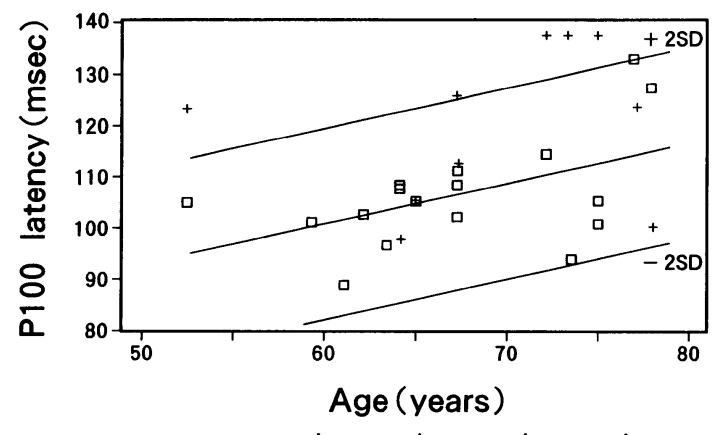

$\square$; non-demented +; demented

図4 パーキンソン病における $\mathrm{P} 100$ 潜時と年齢との 関係. $\mathrm{nD}$ 群においてのみ有意な相関関係がある $(\mathrm{r}=$ $0.516, \mathrm{p}<0.05)$. D 群10例のらち 5 例が, $\mathrm{nD}$ 群の 95\%信頼限界域を越えている。

(標準偏差)の範囲内に含まれるのに対して, D 群は10 例中 5 例が2SDの範囲を越えて延長していた（図 4 ）.
平均 P100振幅は C 群, $\mathrm{P}$ 病のいずれにおいても, 加龄 との間に一定の傾向を認めなかった。

\section{考察}

P病における pattern reversal VEPの異常を Bodis-Wollner ら ${ }^{1)}$ が報告して以来, $\mathrm{P}$ 病における潜在 的な視覚伝導障害の存在が注目されている。彼らは, P 病において延長している P100潜時が L-dopa 投与 によって正常化すると報告し, 網膜レベルでの dopamine の関与を予想している2). 彼らはさらに, ラットに dopamine receptor blockadeを投与するこ とにより遅延した視覚誘発電位の潜時が, dopamine agonist を投与することにより短縮することを示し， VEP における dopamine の関与を裏付けている ${ }^{12)}$. Kupersmith ら3) も, P 病における P100潜時が重症度 と相関して延長すると報告している. しかし, Dinner $ら^{13)}$ は, P 病と正常対象群との間に P100潜時の有意な 差異を認めないと報告して打り, Nightingale ら4) \& $\mathrm{P}$ 病においてはP100潜時は延長せず P100振幅のみが有 意に低下すると報告している.上記の如く, P病におけ る pattern reversal VEP所見は様々なものが報告さ れており，その障害レベルについても一定の見解が得 られていない、P病に怙ける VEP 異常が網膜での障 害に由来するとの説の根拠として, 網膜の amacrine 細胞はdopamine 作動系であること, 網膜電位 (electroretinogram, 以下 ERG) にて異常が認められ ること,さらに左眼と右眼刺激間の差である interocular difference を示す例が多いことが挙げられてい る。これに対し Calzetti ら ${ }^{14)}$ は, P 病において有意に P100潜時が延長し P100振幅が低下すると報告してい るが, VEP と ERGが必ずしも相関して変動しないこ とより中权の視覚路における障害の関与を想定してい る.これら P 病における VEP 所見の多様性の原因と しては, 対象とする $\mathrm{P}$ 病患者の病期と重症度, L-dopa 等の投薬の有無, 及び P 病において subtype が存在す る可能性を考慮する必要がある.P病では dopamine 以外の neurotransmitterの異常も指摘されてお $\eta^{15)}$, 多様な病態が存在するものと予想される.

我々の痴呆の有無による検討では, $\mathrm{P}$ 病では $\mathrm{D}$ 群に おいてのみ $\mathrm{nD}$ 群, C 群に比して有意に潜時が延長し ていた. P100潜時は, $\mathrm{nD}$ 群においてのみ年齢との有意 な相関を認めたが，D群においては年齢・重症度のい ずれとも明らかな相関は認められなかった。 P100振幅 については， 3 群間で有意な差異を認めなかった。 
今回の検討で, $\mathrm{P}$ 病とくに $\mathrm{D}$ 群における $\mathrm{P} 100$ 潜時 の延長が重症度と相関しなかった原因として, 服用中 の L-dopa が影響している可能性がある。他の可能性 として，P病では網膜での dopamine 作動系の障害だ けではなく, 中权の視覚路の障害も考慮する必要があ る。 D群においては，P100の発現に関与する外側膝状 体より第一次視覚野に至る中枢の視覚路に障害をきた している可能性がある. 更に, P100の振幅に変化がな く, 潜時の及延長することは, 神経細胞の減少とか軸 索変性よりはむしろシナプスでの neurotransmitter や receptor の障害を示唆するものと思われる ${ }^{11)} . \mathrm{D}$ 群 においてのみ $\mathrm{P} 100$ 潜時が延長することは, $\mathrm{P}$ 病に打け る中枢の視覚路の障害と痴呆が同一のメカニズムに由 来する可能性を示唆している，即ち，痴呆を有する $\mathrm{P}$ 病においては dopamine 以外の neurotransmitter が 関与しており, pattern reversal VEP の異常も同様の 機序で発現している可能性がある。P病に扔ける痴呆 の発現に acetylcholine の関与を示唆する報告もある が, 異論もあり末だ結論がでない(16)17).一方, 外側膝状 体より視覚路に至る経路には acetylcholine 以外の neurotransmitter が関与している可能性が高い18). 従って, 痴呆を有するP 病の VEP異常には, dopamine や acetylcholine 以外の neurotransmitter の関与も考慮しなければならない。アルッハイマー (A) 病に打いては pattern reversal VEP では異常を 認めず, flash VEP の P2においてのみ潜時が延長する との報告があり ${ }^{19200)}$, VEP は $\mathrm{P}$ 病と $\mathrm{A}$ 病に括ける痴 呆の鑑別上有用となる可能性がある.

P 病における pattern reversal VEP 異常のメカニ ズムには不明な点が多く, pattern reversal VEP と ERG や flash VEP との対比や，L-dopa や抗コリン剂 等の薬剤の影響を検討することが今後の課題である。 知的能力と VEP 所見の経時的変化を検討することに より，P病における痴呆のメカニズムの解明に役立つ ものと思われる。

本論文の要旨は，第33回日本老年医学会総会（1991年11 月, 横浜)にて発表した。本研究に御協力頂いた, 本学中央 臨床検査部平山宏美氏に深謝いたします。

\section{文献}

1) Bodis-Wollner I, Yahr MD: Measurements of visual evoked potentials in Parkinson's disease. Brain 101 : 661-671, 1978.
2) Bodis-Wollner I, Yahr MD, Mylin L, Thornton $\mathrm{J}$ : Dopaminergic deficiency and delayed visual evoked potentials in humans. Ann Neurol 11: 478-483, 1982.

3) Kupersmith MJ, Shakin E, Siegel IM, Lieberman A: Visual system abnormalities in patients with Parkinson's disease. Arch Neurol 39: 284-286, 1982.

4) Nightingale S, Mitchell KW, Howe JW: Visual evoked cortical potentials and pattern electroretinograms in Parkinson's disease and control subjects. J Neurol Neurosurg Psychiatry $49: 1280-1287,1986$.

5) Boller F, Mizutani T, Roessmann U, Gambetti P: Parkinson disease, dementia, and Alzheimer disease: Clinicopathological correlations. Ann Neurol $7: 329-335,1980$.

6) Tachibana H, Takeda M, Sugita M: Shortlatency somatosensory and brainstem auditory evoked potentials in patients with Parkinson's disease. Int J Neurosci $44:$ 321-326, 1989.

7) 戸田和夫：事象関連電位からみた Parkinson 病 の認知機能一P3a 成分と $\mathrm{P} 3 \mathrm{~b}$ 成分一. 日老医誌 28:801-809, 1991.

8) American Psychiatric Association: Diagnostic and Statistical Manual of Mental Disorders. DSM-III-R. American Psychiatric Association, Washington DC, 1987, p107-109.

9) Folstein MF, Folstein SE, McHugh PR: "Mini-mental State". A practical method for grading the cognitive state of patients for the clinician. J Psychiatr Res 12 : 189-198, 1975.

10) Wallenstein $S$, Zucken $C Z$, Fleiss JL: Some statistical methods useful in circulation research. Cir Res $47: 1-9,1980$.

11）黑岩義之, Celesia GG：視覚誘発電位. 西村書店, 東京, 1989, p35-55.

12) Onofrj M, Bodis-Wollner I: Dopaminergic deficiency causes delayed visual evoked potentials in rats. Ann Neurol 11:484-490, 1982.

13) Dinner DS, Lüders H, Hanson M, Lesser RP, Klem G: Pattern evoked potentials (PEPs) in Parkinson's disease. Neurology $35: 610-613$, 1985.

14) Calzetti S, Franchi A, Taratufolo G, Groppi E : Simultaneous VEP and PERG investigations in 
early Parkinson's disease. J Neurol Neurosurg Psychiatry 53: 114-117, 1990.

15) Scatton B, Javoy-Agid F, Rouquier L, Dubois B, Agid Y: Reduction of cortical dopamine, noradrenaline, serotonin and their metabolites in Parkinson's disease. Brain Res $275: 321-328$, 1983.

16) Whitehouse PJ, Hedreen JC, White CL III, Price DL: Basal forebrain neurons in the dementia of Parkinson disease. Ann Neurol 13 : 243-248, 1983.

17) Ruberg M, Ploska A, Javoy-Agid F, Agid Y : Muscarinic binding and choline acetyltransferase activity in parkinsonian subjects with refer- ence to dementia. Brain Res $232: 129-139$, 1982.

18) Shute CCD, Lewis PR: The ascending cholinergic reticular system : Neocortical olfactory and subcortical projections. Brain 90 : 497-520, 1967.

19) Wright CE, Harding GFA, Orwin A : Presenile dementia-The use of the flash and pattern VEP in diagnosis. Electroencephalogr Clin Neurophysiol $57: 405-415,1984$.

20) Philpot MP, Amin D, Levy R: Visual evoked potentials in Alzheimer's disease : Correlations with age and severity. Electroencephalogr Clin Neurophysiol $77: 323-329,1990$.

Abstract

\title{
Correlation of Visual Evoked Potentials with Dementia in Parkinson's Disease
}

\author{
B. Okuda, H. Tachibana, K. Kawabata, M. Takeda, K. Toda and M. Sugita
}

There has been some debate regarding abnormalities in visual evoked potentials (VEP) in Parkinson's disease (PD). To elucidate the mechanism causing abnormal VEP, we investigated the relationship between VEP and mental function in PD patients. Pattern reversal VEP was recorded in PD patients $(n=27)$ and age-matched control subjects $(n=14)$. PD patients consisted of two subgroups; $\mathrm{PD}$ without dementia ( $\mathrm{nD} \cdot \mathrm{PD} ; \mathrm{n}=17$ ) and $\mathrm{PD}$ with dementia (D-PD; $n=10)$. Dementia was evaluated according to the criteria for dementia assigned in DSM III-R, and mental faculties were estimated by using the mini-mental state examination (MMSE). In pattern VEP recordings, P100 latency and amplitude were measured for each eye stimulated. No patient or control subject had impairment of corrected visual acuity or ophthalmological disease. There was no significant difference in age among the three groups (D-PD, nD-PD and control subjects). D-PD patients showed significantly prolonged

Fifth Department of Internal Medicine, Hyogo College of Medicine
P100 latency compared to $\mathrm{nD}$-PD patients and control subjects $(\mathrm{p}<0.05)$. With respect to $\mathrm{P} 100$ amplitude, no significant difference was shown among the three groups. In PD patients, there was a rough correlation between P100 latency and MMSE score. No correlation was found between P100 amplitude and MMSE score. In control subjects, P100 latency did not correlate with advancing age. In PD patients, nD-PD patients showed a significant correlation between P100 latency and age, whereas D-PD patients presented no correlation. Abnormal VEP in PD has been mostly ascribed to dopaminergic deficiency in the retina. The present study, however, suggests that dysfunction in the central visual system plays a role in abnormal pattern VEP in PD, particularly in D-PD. Since patients with Alzheimer's disease have abnormal flash VEP but normal pattern VEP, VEP seems to be valid for differential diagnosis of dementing diseases.

Key words: Parkinson's disease, Visual evoked potentials, Dementia

(Jpn J Geriat 29: 475-479, 1992) 